\title{
Peningkatan Kualitas Infrastruktur Permukiman Melalui Pemberdayaan Masyarakat Desa/Kelurahan Berbasis Data Base Digital Keruangan (SPASIAL) Di Kabupaten Wajo
}

\author{
Abdul Rachman Rasyid ${ }^{1 *}$, Andi Lukman Irwan ${ }^{2}$, Laode Muhammad Asfan Mujahid ${ }^{1}$, Ihsan $^{1}$, \\ Mimi Arifin ${ }^{1}$, M. Yahya ${ }^{1}$, Firman Husain ${ }^{1}$ \\ Fakultas Teknik Universitas Hasanuddin ${ }^{1}$ \\ Fakultas Ilmu Sosial dan Ilmu Politik Universitas Hasanuddin ${ }^{2}$ \\ rachman_rasyid@yahoo.com ${ }^{1 *}$
}

\begin{abstract}
Abstrak
Kabupaten Wajo merupakan salah satu kabupaten yang memiliki dampak penting bagi perkembangan dan kemajuan Provinsi Sulawesi Selatan. Sejalan dengan itu sarana produksi pertanian akan dikembangkan melalui mekanisme pengolahan hingga industri kreatif. Pada sektor irigasi, akan diarahkan pada pengembangan Irigasi berskala besar dan skala kecil pedesaan malalui Embung Buatan, Revitalisasi rawa dan pesisir danau. Sementara diperkotaan akan dilaksanakan penataan lingkungan pemukiman, terutama pinggiran Danau Tempe dalam wilayah Kota Sengkang sebagai Ibu Kota Kabupaten Wajo. Tujuan dari kegiatan ini yakni terwujudnya kemudahan akses bagi masyarakat untuk air minum dan tersedianya data akurat terkait kondisi lokasi wilayah berbasis Sistem Informasi Geografi (SIG). Pendekatan yang digunakan dalam kegiatan ini adalah survei lapangan terkait kondisi eksisting lokasi dengan pendampingan pada masyarakat, peningkatan pengetahuan berupa pelatihan atau penyuluhan (sosialisasi) yang bertujuan pemecahan masalah yang ada pada Desa/Kelurahan di Kecamatan Tempe Kabupaten Wajo, serta pelatihan dan pemanfaatan data base digital terkait profil dan potensi wilayah.

Hasil kegiatan yang diperoleh bahwa wilayah Kabupaten Wajo khususnya di kecamatan Attakae, Maddukelleng, Pattirosompe dan Tempe memeiliki beberapa permasalahan yaitu, sistem persampahan, jaringan jalan, bangunan yang tidak layak huni dan air bersih yang belum memadai. Namun terdapat potensi yang dapat dikembangkan untuk meningkatkan perekonomian wilayah seperti, industri sutra dan indsutri kayu.
\end{abstract}

Kata Kunci: GIS; keruangan; infrastruktur; masyarakat; perkotaan.

\begin{abstract}
Wajo Regency is one of the districts that have a role in the development and progress of South Sulawesi Province. Therefore, agricultural production facilities will be developed through processing mechanisms to the creative industries. Irrigation will be directed at the development of large-scale and small-scale rural irrigation through artificial embankments, revitalization of swamps and lakes. Whereas in urban areas a residential environment will be held an adjustment, especially near the of Lake Tempe in the area of Sengkang as the Capital of Wajo Regency. The purpose of this study is to find easy access for the community to drinking water and to provide accurate data related to Geographic Information System (GIS)-based regional location conditions. The approach used in this activity is a field survey related to the existing condition of the location by assisting the community, increasing knowledge by training or counseling aimed at solving existing problems in the village / subdistrict in Tempe Subdistrict, Wajo Regency, as well as training and utilizing digital databases related to the profile and potential of the city.

The results of the study obtained were that some districts had several problems, namely, solid waste systems, road networks, inadequate buildings and inadequate clean water especially in Attakae, Maddukelleng, Pattirosompe and Tempe. However, there is potential that can be developed to improve the regional economy, such as the silk industry and wood industry.
\end{abstract}

Keywords: GIS; spasial; infrastructures; community; urban. 


\section{Pendahuluan}

Visi Kabupaten Wajo 2005-2025 yakni : "Mewujudkan Kesejahteraan Masyarakat Wajo Dengan Jiwa Kemandirian dan Pemerintah yang Demokratis Bernafaskan Keagamaan." Adapun Misi yang disusun berdasarkan uraian Visi 2005-2025 diatas diantaranya adalah meningkatkan akselerasi pembangunan infrastruktur dalam mendukung pengembangan pusat-pusat produksi pertanian dan pemasaran komoditas unggulan untuk percepatan kesejahteraan masyarakat, menciptakan kondisi yang kondusif untuk pertumbuhan ekonomi berbasis masyarakat sehingga dapat mendorong peningkatan pendapatan rakyat dan daerah dan mengembangkan sistem perencanaan yang pertisipatif untuk mendukung kebijakan pembangunan berorientasi lingkungan hidup berbasis pedesaan dan perkotaan.

Implementasi dalam pokok-pokok program sebagai induk dari program yang direncanakan, yakni pengembangan sistem perencanaan daerah yang partsipatif, program ini diarahkan untuk mewujudkan suatu sistem perencanaan yang partisipatif, dengan demikian diharapkan bahwa perencanaan program dan kegiatan Pemerintah Kab. Wajo betul-betul mencerminkan aspirasi masyarakat yang dapat di akomodir dalam APBD sesuai dengan kondisi keuangan daerah. Perluasan jangkauan dan kualitas infrastruktur berbasis pedesaan dan perkotaan, program bidang Infrastruktur diarahkan bukan saja perluasan dan peningkatan kualitas jalan antar desa dan kecamatan, melainkan lebih pada upaya mendukung akses produksi unggulan kepada pusat-pusat pembangunan produksi antara wilayah. Secara umum permasalahan yang dialami oleh Kelurahan/Desa yang termasuk dalam program tersebut, yaitu kurangnya akses masyarakat untuk air minum, masih terdapatnya kawasan kumuh dan masih kurangnya akses terhadap sanitasi, perlunya peningkatan partisipasi masyarakat pengguna atau pemakai bantuan program tersebut dan tidak tersedianya data akurat dan sulitnya akses terhadap data tersebut serta lemahnya manajemen pengelolaan data khususnya yang berkaitan dengan lokasi, kondisi pada wilayah tersebut.

Dari uraian program dan permasalahan yang di atas, maka beberapa rencana kegiatan pendampingan pada masyarakat yang akan dilaksanakan adalah, pendampingan kegiatankegiatan pokok yang tertuang dalam KKN Tematik Infrastruktur yaitu Pembentukan Kelompok Swadaya Masyarakat (KSM), pelatihan teknis Pengelolaan Air Limbah bagi KSM Sanimas serta peningkatan pengetahuan melalui Sosialisasi dan edukasi partisipasi masyarakat dalam pengelolaan Air Limbah Domestik (Pada daerah yang berpotensi di bangun IPAL Komunal). Sosialisasi pengolahan sampah terpadu melalui program rencana pengurangan sampah (3R) dan kampanye dan sosialisasi terhadap masyarakat untuk melaksanakan pola hidup bersih dan sehat yang terkait sanitasi yang berbasis kelembagaan melalui sekolah-sekolah maupun langsung kepada masyarakat itu sendiri. Pembuatan dan Penyusunan Peta Tapak terkait lokasi dan kondisi wilayah sasaran melalui keterlibatan masyarakat secara aktif dan mahasiswa sebagai pendamping guna mewujudkan data base digital yang lebih mudah dan efisien. Penyusunan data profil dan potensi Desa/Kelurahan berbasis Sistem Informasi Geografis (SIG) dengan output peta digital berbasis web offline.

\section{Latar Belakang Teori}

\subsection{Permukiman Kumuh}

Menurut UU No. 4 Tahun 1992 tentang Perumahan dan Permukiman, perumahan berada dan merupakan bagian dari permukiman, perumahan adalah kelompok rumah yang berfungsi sebagai 
lingkungan tempat tinggal atau lingkungan hunian yang dilengkapi dengan prasarana dan sarana lingkungan (pasal 1 ayat 2). Pasal 4 Undang-Undang Nomor 4 Tahun 1992 menyebutkan bahwa penataan perumahan dan permukiman berlandaskan asas manfaat, adil dan merata, kebersamaan dan kekeluargaan, kepercayaan pada diri sendiri, keterjangkauan, dan kelestarian lingkungan hidup. Jadi, pemukiman adalah suatu wilayah atau area yang ditempati oleh seseorang atau kelompok manusia. Pemukiman memiliki kaitan yang cukup erat dengan kondisi alam dan sosial kemasyarakatan sekitar. Pemukiman sering disebut perumahan dan atau sebaliknya. Pemukiman berasal dari kata housing dalam bahasa Inggris yang artinya adalah perumahan dan kata human settlement yang artinya pemukiman.

Perumahan memberikan kesan tentang rumah atau kumpulan rumah beserta prasarana dan sarana ligkungannya. Perumahan menitiberatkan pada fisik atau benda mati, yaitu houses dan land settlement. Sedangkan pemukiman memberikan kesan tentang pemukim atau kumpulan pemukim beserta sikap dan perilakunya di dalam lingkungan, sehingga pemukiman menitikberatkan pada sesuatu yang bukan bersifat fisik atau benda mati yaitu manusia (human). Dengan demikian perumahan dan pemukiman merupakan dua hal yang tidak dapat dipisahkan dan sangat erat hubungannya, pada hakekatnya saling melengkapi.

Kumuh adalah kesan atau gambaran secara umum tentang sikap dan tingkah laku yang rendah dilihat dari standar hidup dan penghasilan kelas menengah. Dengan kata lain, kumuh dapat diartikan sebagai tanda atau cap yang diberikan golongan atas yang sudah mapan kepada golongan bawah yang belum mapan. Slum's merupakan lingkungan hunian yang legal tetapi kondisinya tidak layak huni atau tidak memnuhi persyaratan sebagai tempat permukiman (Utomo Is Hadri, 2000). Slum's yaitu permukiman diatas lahan yang sah yang sudah sangat merosot (kumuh) baik perumahan maupun permukimannya (Herlianto, 1985).

Diana Puspitasari dari Dinas Tata Ruang dan Permukiman (Distarkim) Kota Depok mengatakan, definisi permukiman kumuh berdasarkan karakteristiknya adalah suatu lingkungan permukiman yang telah mengalami penurunan kualitas. Dengan kata lain memburuk baik secara fisik, sosial ekonomi maupun sosial budaya. Dan tidak memungkinkan dicapainya kehidupan yang layak bahkan cenderung membahayakan bagi penghuninya.

\subsection{Sistem Informasi Geografis (SIG)}

Geografi adalah ilmu yang mempelajari permukaan bumi dengan menggunakan pendekatan keruangan, ekologi dan kompleks wilayah. Sistem informasi geografis (Geographic Information System) adalah sistem informasi khusus yang mengelola data yang memiliki informasi spasial (bereferensi keruangan). Atau dalam arti yang lebih sempit, adalah sistem komputer yang memiliki kemampuan untuk membangun, menyimpan, mengelola dan menampilkan informasi bereferensi geografis, misalnya data yang diidentifikasi menurut lokasinya, dalam sebuah database. Subaryono (2005) mendefinisikan SIG sebagai suatu himpunan terpadu dari hardware, software, data, dan lineware (orang-orang yang bertanggung jawab dalam mendesain, mengimplemetasikan dan menggunkan SIG). ESRI (Environmental System Research Institute) mendefenisikan SIG adalah kumpulan yang terorganisir dari perangkat keras computer, perangkat lunak, data geografis dan personil yang dirancang secara efisien untuk memperoleh, menyimpan, meng-update, memanipulasi, menganalisis dan menampilkan semua bentuk informasi yang bereferensi geografis.

\section{Metode Pelaksanaan}


Keberhasilan pelaksanaan program peningkatan kualitas permukiman kumuh dapat terwujud dengan baik jika terwujudnya keterlibatan stake holders baik masyarakat dan pemerintah Kab. Wajo serta dukungan dari Ditjen Cipta Karya KemenPUPR beserta perguruan tinggi, yang saling bersinergi. Terkhusus bagi perguruan tinggi yang keterlibatannya sesuai dengan Tri Darma Perguruan Tinggi yaitu a) Pendidikan dan Pengajaran, b) Penelitian dan Pengembangan, dan c) Pengabdian Kepada Masyarakat. Adapun rincian pelaksanaan kegiatan ini adalah sebagai berikut :

a) Persiapan dan pembekalan yaitu persiapan dan pembekalan dilakukan sebagai awal koordinasi dan penyamaan kesepahaman bagi para mahasiswa dan pemerintah daerah Kabuapaten Wajo terkait pelaksanaan program. Pembekalan ini akan diselengarakan di UNHAS dengan pemateri dari Ditjen Cipta Karya KemenPUPR dan DPL UNHAS.

b) Materi pembelajaran dan pelatihan teknis bagi mahasiswa peserta KKN PPMUH terutama pelaksanaan program-program utama KKN Tematik infrastruktur dan materi tambahan seperti penyusunan data base spasial terkait infrastruktur dan permukiman.

c) Evaluasi pelaksanaan kegiatan secara berkala oleh DPL UNHAS.

d) Diseminasi hasil program pada akhir kegiatan.

Keterlibatan Mahasiswa dan Dosen Pembimbing Lapangan (DPL) diharapkan dapat mempercepat terwujudnya tujuan kegiatan tersebut serta menjadi pendamping bagi masyarakat khususnya dalam meningkatkan partisipasi dan pengetahuan agar dapat berdaya guna dan masyarakat mampu mengatasi persoalan persoalan terkait penanganan permukiman kumuh di wilayahnya. Adapun metode yang digunakan dalam pelaksanaan kegiatan, antara lain :

a) Survey lapangan terkait kondisi eksisting lokasi dengan pendampingan pada masyarakat

b) Peningkatan pengetahuan berupa pelatihan atau penyuluhan (sosialisasi) yang bertujuan pemecahan masalah yang ada pada Desa/Kelurahan di Kecamatan Tempe Kabupaten Wajo.

c) Pelatihan dan pemanfaatan data base digital terkait profil dan potensi wilayah.

\section{Hasil dan Diskusi}

\subsection{Keluarahan Attakae}

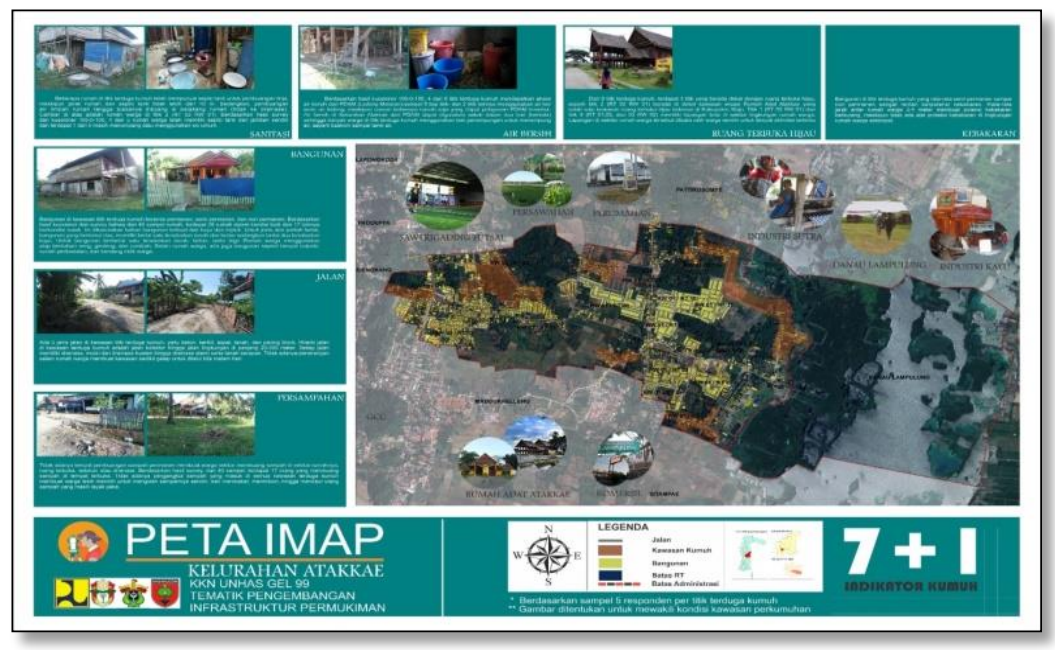

Gambar 1. Peta Identifikasi Masalah dan Analisis Potensi Kelurahan Atakkae 
Berdasarkan survei dilapangan pada Kelurahan Attakae yang menjadi objek kagiatan ditemukan beberapa permasalahan yakni, sanitasi, air bersih, ruang terbuka hijau, kebakaran, bangunan, jalan dan persampahan. Selain itu, terdapat potensi yang dapat dikembangkan yakni, industri sutra, danau Lampulung dan industri kayu. Dapat dilihat pada gambar 2.

\subsection{Kelurahan Maddukkelleng}

Berdasarkan survei dilapangan pada Kelurahan Maddukelleng yang menjadi objek kagiatan ditemukan beberapa permasalahan yakni, sanitasi, air bersih, ruang terbuka hijau, kebakaran, bangunan tidak layak huni, jalan tidak sesuai standar dan persampahan. Selain itu, terdapat potensi yang ada seperti beberapa sarana prasarana yang cukup memadai, seperti sekolah dan tempat peribadatan. Dapat dilihat pada gambar 3.
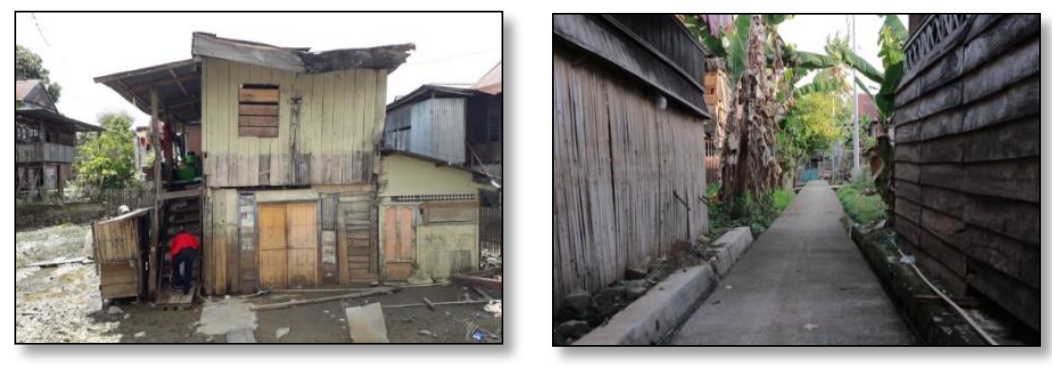

Gambar 2. Kondisi Permasalahan Eksisting
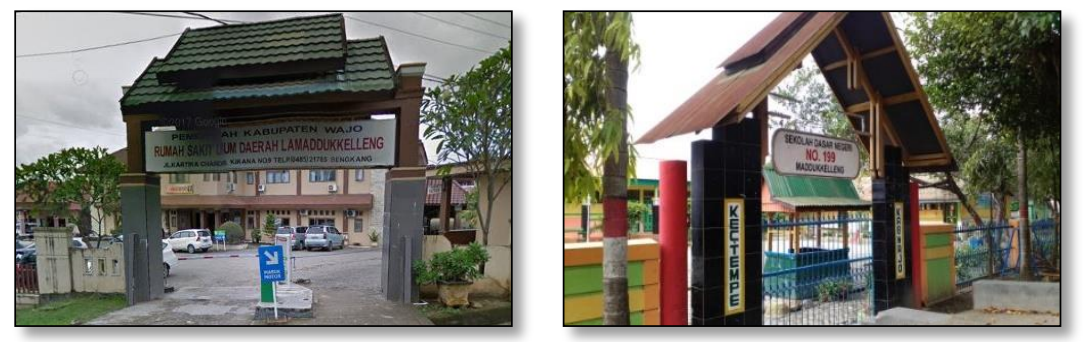

Gambar 3. Kondisi Fasilitas Sarana Prasarana

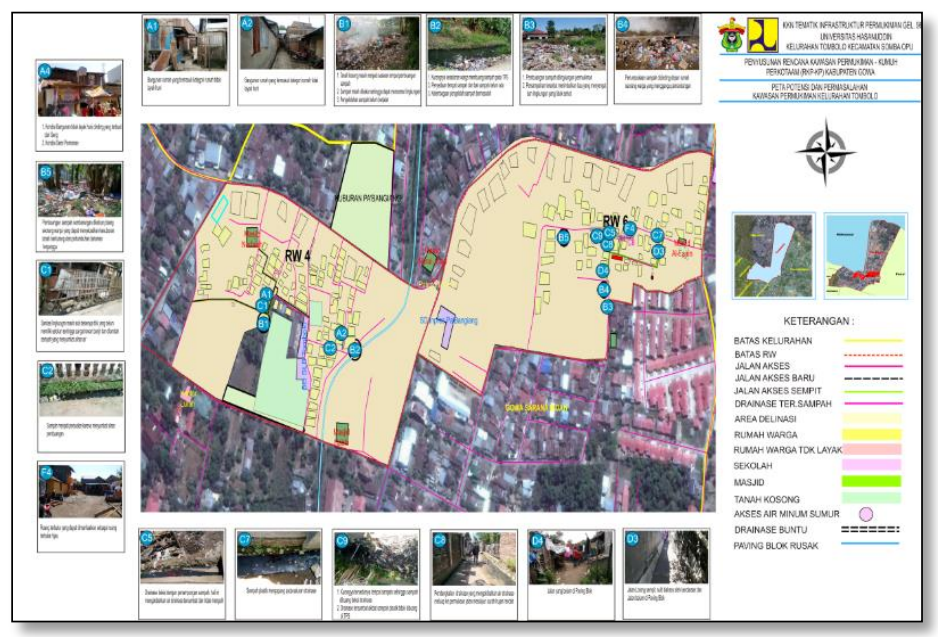

Gambar 4. Peta Identifikasi Masalah dan Analisis Potensi Kelurahan Maddukkelleng 


\subsection{Kelurahan Pattirosompe}

Berdasarkan survei dilapangan pada Kelurahan Maddukelleng yang menjadi objek kagiatan ditemukan beberapa permasalahan yakni, sebagian besar status rumah tangga MBR atau sekitar 91\%, jalan yang tidak memenuhi standar SNI, bangunan yang ada tergolong tidak layak huni, serta kundisi air bersih di dalam kawasan belum cukup memadai.

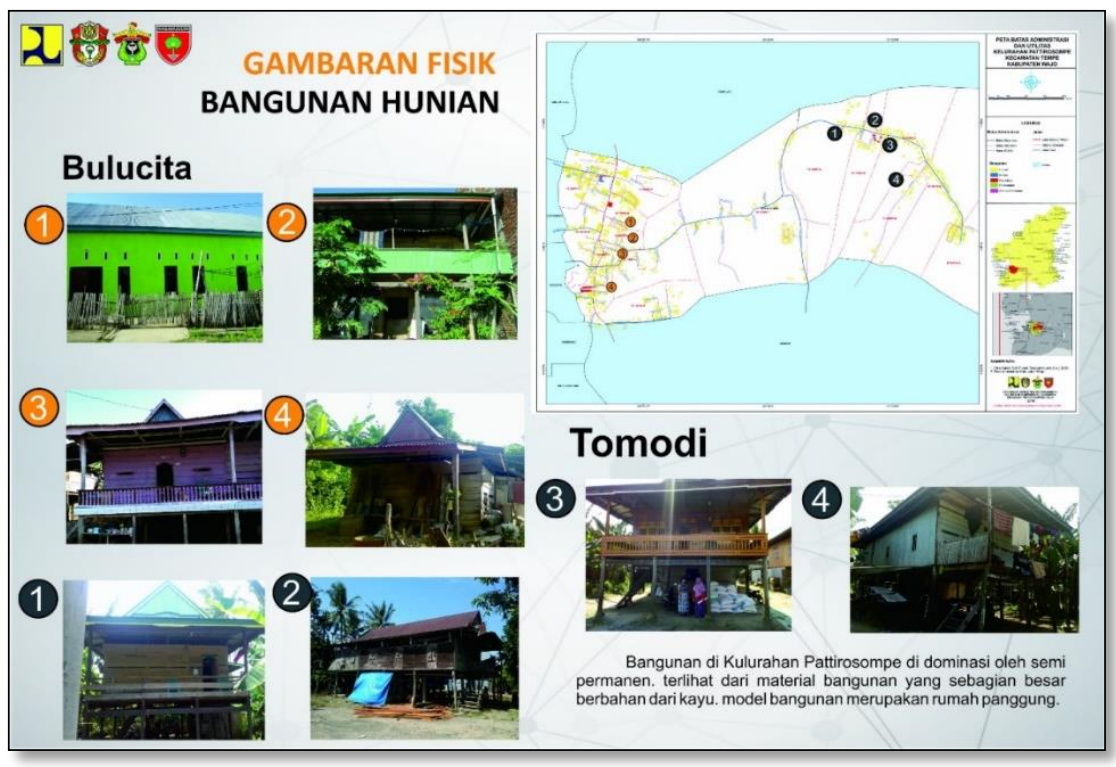

Gambar 5. Peta Identifikasi Masalah dan Analisis Potensi

Bangunan Hunian Kelurahan Pattirosompe

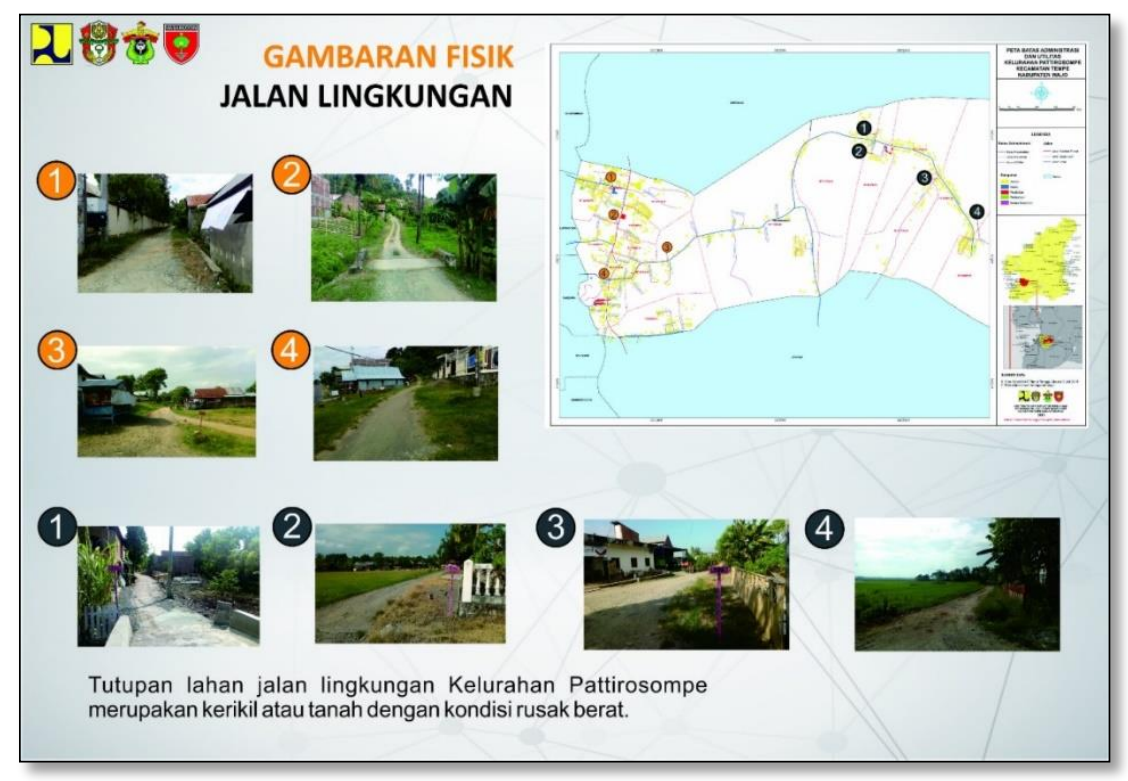

Gambar 6. Peta Identifikasi Masalah dan Analisis Potensi Jalan Lingkungan Kelurahan Pattirosompe 


\subsection{Keluarahan Tempe}

Berdasarkan survei dilapangan pada Kelurahan Maddukelleng yang menjadi objek kagiatan ditemukan beberapa permasalahan yakni, belum adanya sumber air bersih yang memadai (PDAM) atau masih secara tradisional (sungai), kondisi bangunan perumahan sebagian besar tergolong layak huni, kondisi jalan yang berbatu serta sistem persampahan yang masih menggunakan cara tradisional (dibakar dan dibuang ke sungai). Namun terdapat potensi yang sedang direncakan oleh pemerintah kabupaten terkait penanganan masalah yang terjadi diantaranya, rencana pembangunan jalan beton, perbaikan bangunan hunian secara swadaya, pembangunan pipa PDAM, pengadaan sarana dan prasarana persampahan dan pengadaan alat pemadam kebakaran.
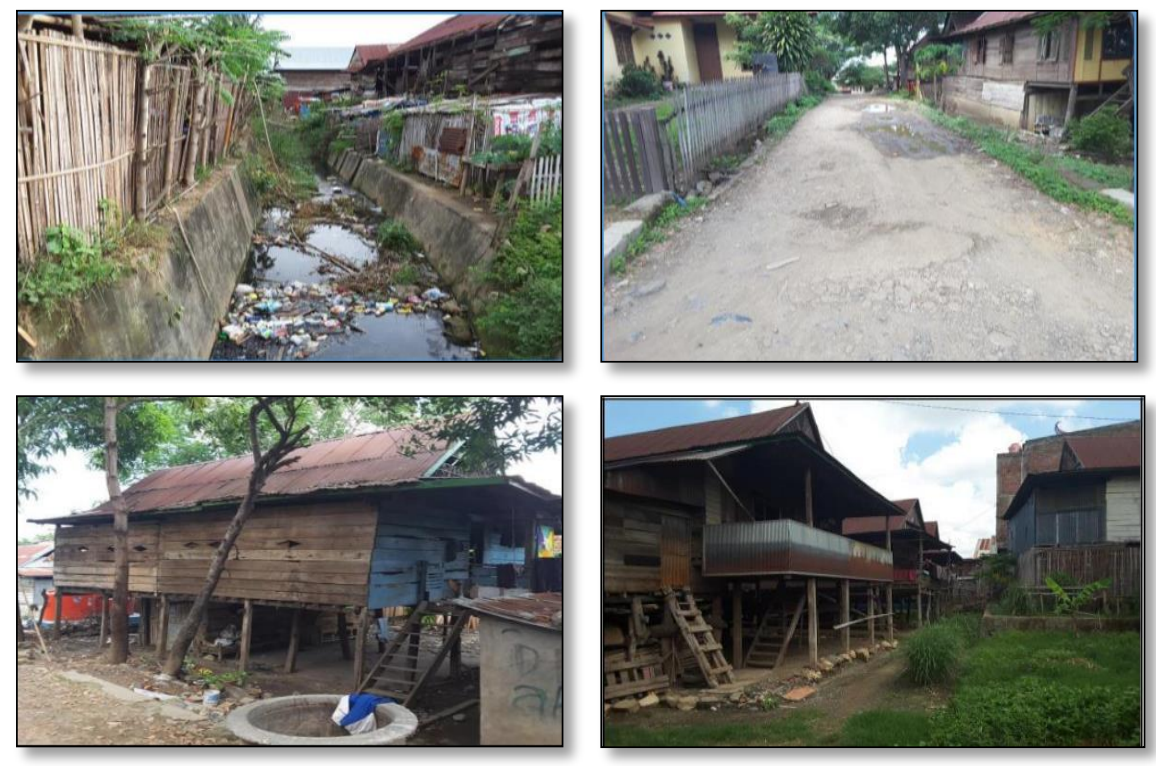

Gambar 7. Kondisi Permasalahan Eksisting

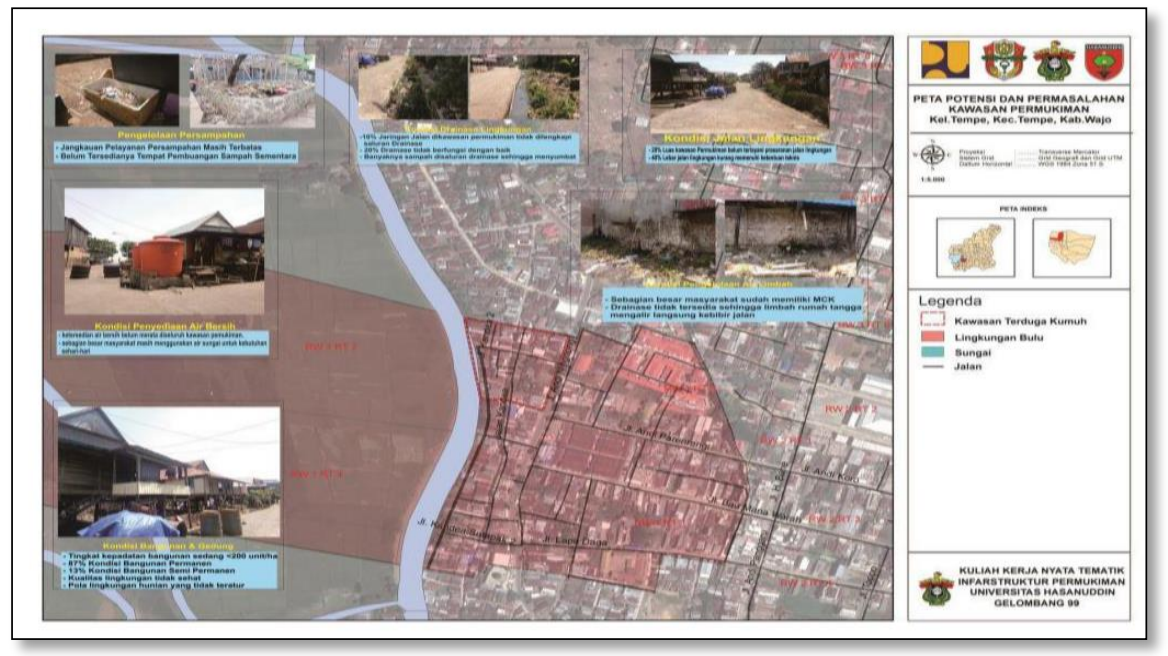

Gambar 8. Peta Identifikasi Masalah dan Analisis Potensi Kelurahan Tempe Lingkungan Bulu 


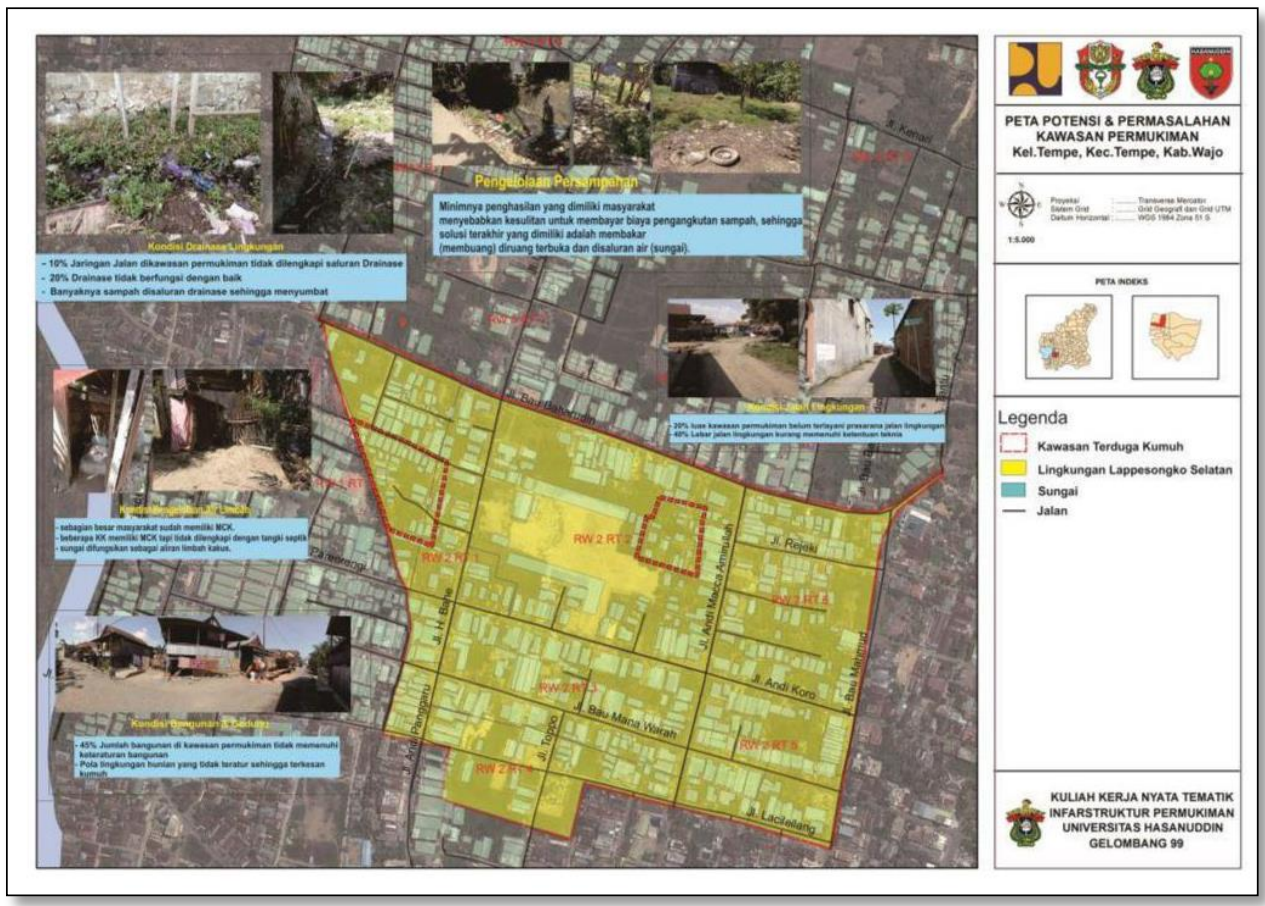

Gambar 9. Peta Identifikasi Masalah dan Analisis Potensi Kelurahan Tempe Lingkungan Lappesongko Selatan

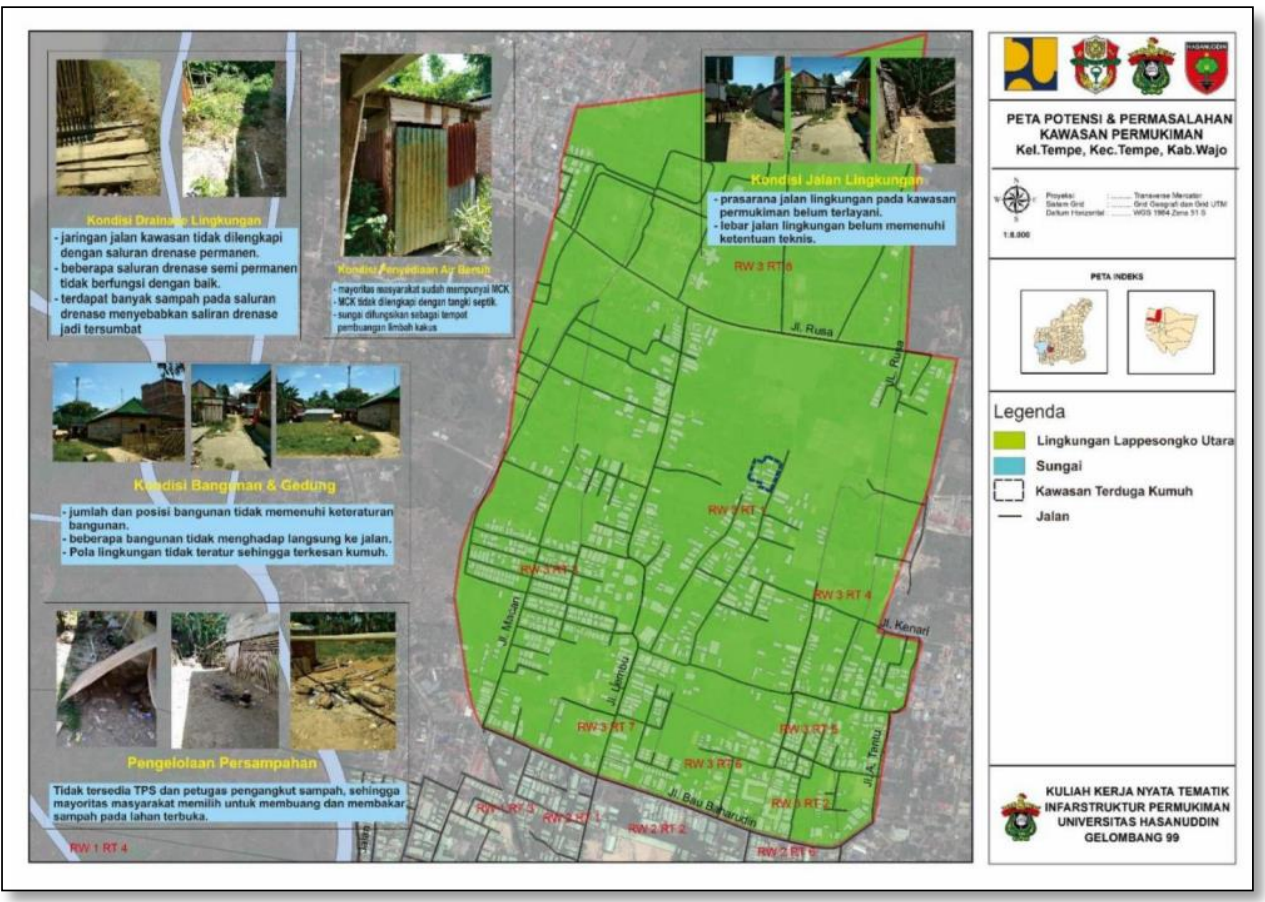

Gambar 10. Peta Identifikasi Masalah dan Analisis Potensi Kelurahan Tempe Lingkungan Lappesongko Utara 


\section{Kesimpulan}

Berdasarkan hasil interpretasi titik-titik sounding geolistrik, maka kondisi air tanah di daerah survei dapat direkomendasikan sebagai berikut;

a. Sebagian besar di lokasi kegiatan atau sekitar $75 \%$ dari total luas wilayah pada Kelurahan Attakae, Madukelleng, Pattirosompe dan Tempe memiliki permasalahan yang sama yaitu air bersih, bangunan tidak layak huni, jalan yang tdk sesuai standar, serta sistem persampahan masih secara tradisional (dibakar atau dibuang ke sungai).

b. Pada lokasi kegiatan terdapat beberapa potensi wilayah yang dapat dikembangkan sebagai nilai jual serta dapat meningkatkan kualitas hidup masyarakat dan ekonomi di wilayahnya seperti industri sutra, danau lampulung dan industri kayu

\section{Ucapan Terima Kasih}

Ucapan Terima Kasih Disampaikan Kepada Mahasiswa KKN Tematik Wajo Gelombang 99.

\section{Daftar Pustaka}

Amri, Nurmaida, 2013, Karateristik Lingkungan Permukiman Kumuh Tepian Sungai Kecamatan Lolaka, Sulawesi Tenggara, Jurnal Jupiter Volume XII No.1

Budiyanto, Eko. 2002. Sistem Informasi Geografis Menggunakan ARC View GIS. Yogyakarta: Andi.

Deputi Pengembangan Kawasan, 2012, Buku Panduan Penanganan lingkungan perumahan dan permukiman kumuh berbasis kawasan TA 2013, Kementrian Perumahan Rakyat Republik Indonesia, Jakarta

Peraturan Menteri Pekerjaan Umum Dan Perumahan Rakyat Republik Indonesia Nomor 02/Prt/M/2016. Tentang Peningkatan Kualitas Terhadap Perumahan Kumuh Dan Permukiman Kumuh.

Riyanto, Putra P.E dan Indelarko H. 2009. Pengembangan Aplikasi Sistem Informasi Geografis berbasis Desktop dan Web. Yogyakarta: Penerbit Gava Media. 